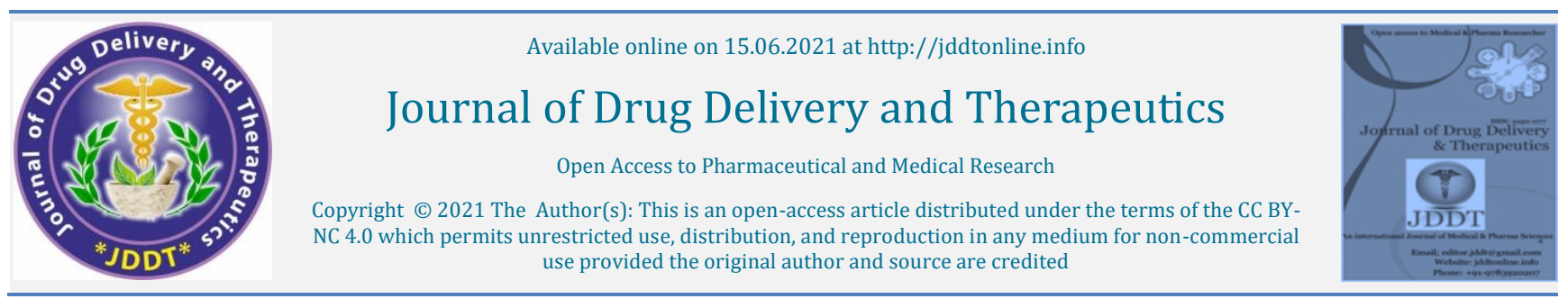

Open Access Full Text Article

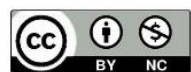

Research Article

\title{
Formulation and Evaluation of Gastroretentive Floating Tablets of Quetiapine Fumarate
}

\author{
Patel Keyur S. ${ }^{*}$, Rao Akshar N. ${ }^{1}$, Patel Deepa R. ${ }^{1}$, (DPatel Dhaval M. ${ }^{2}$, Patel Advaita B. ${ }^{2}$ \\ 1 Kalol Institute of Pharmacy, Kalol, Gandhinagar, Gujarat, India \\ ${ }^{2}$ SAL Institute of Pharmacy, Ahmedabad, Gujarat, India
}

\section{Article Info:}

\begin{tabular}{ll}
\hline & Article History: \\
& Received 11 April 2021 \\
& Accepted 03 June 2021 \\
Available online 15 June 2021
\end{tabular}

Cite this article as:

Patel KS, Rao AN, Patel DR, Patel DM, Patel AB, Formulation and Evaluation of Gastroretentive Floating Tablets of Quetiapine Fumarate, Journal of Drug Delivery and Therapeutics. 2021; 11(3-S):65-73 DOI: http://dx.doi.org/10.22270/jddt.v11i3-S.4833

\footnotetext{
*Address for Correspondence:

Patel Keyur S., Kalol Institute of Pharmacy, Kalol, Gandhinagar, Gujarat, India
}

\section{Abstract}

The objective of the present study was to develop gastroretentive floating tablets of quetiapine fumarate. The gastroretentive floating tablets of quetiapine fumarate were formulated using natrosol $250 \mathrm{HHX}$ as a sustained release polymer and sodium bicarbonate as a gas forming agents. A $3^{2}$ factorial design was employed to study the influence of concentration of natrosol HHX $250\left(\mathrm{X}_{1}\right)$ and concentration of sodium bicarbonate $\left(\mathrm{X}_{2}\right)$ on the dependent variables \% drug release at $1 \mathrm{~h}\left(\mathrm{Y}_{1}\right), \%$ drug release at 8 $\mathrm{h}\left(\mathrm{Y}_{2}\right)$ and floating lag time $\left(\mathrm{Y}_{3}\right)$. The optimized formulation (01) showed floating lag time $49 \pm 3 \mathrm{sec}$ and \% drug release $99.54 \pm 0.81$ at $12 \mathrm{~h}$. The in vitro release of F1-F9 batches were found in between $99.95 \pm 1.18 \%$ to $86.32 \pm 1.71 \%$ at $12 \mathrm{~h}$. Floating lag time of F1-F9 batches were found to be $25 \pm 2 \mathrm{sec}$ to $178 \pm 3 \mathrm{sec}$. FTIR studies shown that there was no interaction between quetiapine fumarate and excipients. From the factorial design batches it was found that floating lag time was decreased with increasing the amount of sodium bicarbonate and decreasing the amount of natrosol 250 HHX. Here \% release of drug was decreased with increase the extent of natrosol 250 HHX. The in-vitro release kinetics revealed Korsmeyer-Peppas model is followed and drug release is by anomalous diffusion.

Keywords: Quetiapine fumarate, Natrosol $250 \mathrm{HHX}$, Sodium bicarbonate, Gastroretentive floating tablets

\section{INTRODUCTION}

Gastroretentive drug delivery systems (GRDDS) are designed to be retained in the stomach for a prolonged time and release their active ingredients and thereby enable sustained and prolonged input of the drug to the upper part of the gastrointestinal tract.1, 2 GRDDS provide extended residence time in the stomach is of specific interest for drugs having an absorption window in the stomach or in the upper portion of small intestine; acting locally in the stomach; those having low solubility at high $\mathrm{pH}$ values; or those unstable in the colonic or intestinal environments. ${ }^{1,3}$ Floating drug delivery systems(FDDS) is one of the great approaches of GRDDS to prolong gastric residence time and to obtain sufficient drug bioavailability. 4, 5 FDDS have a bulk density less than stomach fluids and so remain float in the stomach for a prolong period of time. While the system is floating in the stomach, the drug is liberated slowly at the desired rate from the system. ${ }^{6-8}$ The controlled, slow delivery of drug in the stomach provides sufficient local therapeutic levels for long time and limits the systemic exposure to the drug. 5,9

Quetiapine fumarate $(\mathrm{QF})$ is a psychotropic drug used to cure schizophrenia, bipolar disorder, sudden episodes of mania or depression associated with bipolar disorder. It is an anti-psychotic agent showing serotonin/dopamine binding ratio, dopamine D2-receptor and 5-HT2-receptor ISSN: 2250-1177 blocking effects and resulting minimal extrapyramidal side effects. ${ }^{10,11} \mathrm{QF}$ has mean elimination half life of $6 \mathrm{~h}$ and hence there is a need for twice or thrice daily administration. Quetiapine fumarate shows $\mathrm{pH}$ depended solubility. Quetiapine fumarate is highly soluble in acidic $\mathrm{pH}$ and slightly soluble in basic $\mathrm{pH}$. It would be more helpful to retain the drug in stomach for prolonged period so as to achieve maximum absorption and bioavailability. ${ }^{12}$ So, gastroretentive floating tablet is desirable approach to prolong the residence time of the dosage form in the stomach or upper gastrointestinal tract until the drug is completely released from the system. The aim of this study was to prepare gastroretentive floating tablets of quetiapine fumarate by using natrosol 250 HHX (hydroxyethyl cellulose $250 \mathrm{HHX}$ ) as a sustained release hydrophilic polymer and sodium bicarbonate $\left(\mathrm{NaHCO}_{3}\right)$ as a gas forming agent.

\section{MATERIALS AND METHODS}

\section{Materials}

Quetiapine fumarate was obtained gift sample from Torrent Research Center, Ahmedabad. Natrosol 250 HHX, Avicel PH102 and polyvinylpyrrolidone (PVP K-30) were purchased from Yarrow chem Product, Mumbai. Sodium bicarbonate, citric acid, magnesium stearate and talc were purchased from Chemdyes Corporation, Rajkot, Gujarat. 


\section{Drug and excipient compatibility study by FTIR}

FTIR study carried out to identify the drug sample and to establish drug polymer compatibility in physical mixture of drug and polymers. The FTIR spectra were obtained by using an FTIR spectrometer (FTIR- 8400S, Shimadzu, Japan). The samples were mixed thoroughly with potassium bromide, an infrared transparent matrix, at 1:1 (sample: $\mathrm{KBr}$ ) ratio, respectively. FTIR study was accomplished in the range of $400-4000 \mathrm{~cm}^{-1}$

\section{Preparation of floating Tablet}

Direct compression technique was used to prepare floating tablets of QF. All ingredients were accurately weighed and passed through sieve \# 40 and mixed thoroughly for $10 \mathrm{~min}$. The blend was lubricated with talc and magnesium stearate for $2 \mathrm{~min}$. The lubricated blend was compressed using single rotary tablet compression machine (Karnavati Engineering, Mehsana).

\section{Experimental Design:}

In this design, two factors were evaluated each at three levels and experimental trials were performed using all possible nine combination. In this present study, concentration of natrosol $250 \mathrm{HHX}\left(\mathrm{X}_{1}\right)$ and concentration of sodium bicarbonate $\left(\mathrm{X}_{2}\right)$ were selected as independent variables. The \% in-vitro drug liberate at $1 \mathrm{~h}(\% \mathrm{CDR}$ at $1 \mathrm{~h})\left(\mathrm{Y}_{1}\right)$, in-vitro drug liberate at $8 \mathrm{~h}$ $(\% \mathrm{CDR}$ at $8 \mathrm{~h})\left(\mathrm{Y}_{2}\right)$ and floating lag time (FLT) $\left(\mathrm{Y}_{3}\right)$ were elected as depended responses. A statistical design, incorporating interactive and polynomial terms was applied to check the response. 13

Table 1: Variables in $3^{2}$ Factorial designs

\begin{tabular}{|l|c|c|c|}
\hline \multicolumn{1}{|c|}{ Independent Variables } & \multicolumn{3}{|c|}{ Levels } \\
\cline { 2 - 4 } & $\mathbf{- 1}$ & $\mathbf{0}$ & $\mathbf{+ 1}$ \\
\hline $\mathrm{X}_{1}$ : Natrosol 250 HHX & $60 \mathrm{mg} \mathrm{(24 \% )}$ & $75 \mathrm{mg}(30 \%)$ & $90 \mathrm{mg}(36 \%)$ \\
\hline $\mathrm{X}_{2}$ : Sodium bicarbonate & $25 \mathrm{mg} \mathrm{(10 \% )}$ & $35 \mathrm{mg}(14 \%)$ & $45 \mathrm{mg}(18 \%)$ \\
\hline
\end{tabular}

Dependent variables: $Y_{1}$ : in vitro drug release at $1 \mathrm{~h}$ (\% CDR at 1), Y2: in vitro drug release $8 \mathrm{~h}$ (\% CDR at $8 \mathrm{~h}$ ), $\mathrm{Y}_{3}$ : floating lag time (FLT) (sec),

Table 2 Formulation of factorial batches

\begin{tabular}{|c|c|c|c|c|c|c|c|c|c|}
\hline Ingredients (mg/tab) & F1 & F2 & F3 & F4 & F5 & F6 & F7 & F8 & F9 \\
\hline Quetiapine Fumarate* & 58 & 58 & 58 & 58 & 58 & 58 & 58 & 58 & 58 \\
\hline Natrosol 250 HHX & 60 & 60 & 60 & 75 & 75 & 75 & 90 & 90 & 90 \\
\hline Sod. Bicarbonate & 25 & 35 & 45 & 25 & 35 & 45 & 25 & 35 & 45 \\
\hline Citric Acid & 15 & 15 & 15 & 15 & 15 & 15 & 15 & 15 & 15 \\
\hline Avicel PH102 & 78 & 68 & 58 & 63 & 53 & 43 & 48 & 38 & 28 \\
\hline PVP K30 & 8 & 8 & 8 & 8 & 8 & 8 & 8 & 8 & 8 \\
\hline Talc & 2 & 2 & 2 & 2 & 2 & 2 & 2 & 2 & 2 \\
\hline Magnesium stearate & 4 & 4 & 4 & 4 & 4 & 4 & 4 & 4 & 4 \\
\hline Average weight of tablet & $\mathbf{2 5 0}$ & $\mathbf{2 5 0}$ & $\mathbf{2 5 0}$ & $\mathbf{2 5 0}$ & $\mathbf{2 5 0}$ & $\mathbf{2 5 0}$ & $\mathbf{2 5 0}$ & $\mathbf{2 5 0}$ & $\mathbf{2 5 0}$ \\
\hline
\end{tabular}

* $58 \mathrm{mg}$ of Quetiapine fumarate is equivalent to $50 \mathrm{mg}$ of Quetiapine

\section{Evaluation of floating tablets}

\section{Weight variation}

Twenty (20) tablets from each batch were individually weighed in grams on a digital analytical balance. The average weight and standard deviation were calculated, individual weight of each tablet was also calculated using the same and compared with average weight.

\section{Tablets Thickness:}

The thickness of the tables was determined by using digital vernier calipers. Randomly five tablets from each batch were taken and average values were calculated.

\section{Hardness}

Five tablets will select at random and the hardness of each tablet will measure with Monsanto hardness tester. The hardness is usually measured in terms of $\mathrm{kg} / \mathrm{cm}^{2} .{ }^{13}$

\section{Friability}

The friability test will carried out in Roche friabilator. Ten tablets weighed ( $\left.\mathrm{W}_{\text {initial }}\right)$ at the start and kept in a rotating drum of friability apparatus for 100 revolutions. After ending of 100 revolutions, the tablets again weighed ( $\mathrm{W}_{\text {final }}$ ). The percent loss in weight or friability (f) determined by the formula given below. ${ }^{13}$

$$
\mathrm{F}=\frac{\left(\mathrm{W}_{\text {initial }}\right)-\left(\mathrm{W}_{\text {final }}\right)}{\left(\mathrm{W}_{\text {initial }}\right)} \mathrm{X} 100
$$

\section{Drug Content}

10 QF floating tablets were taken, powdered. The powder equivalent to $58 \mathrm{mg} \mathrm{QF}$ was shifted to a $100 \mathrm{ml}$ volumetric flask and $0.1 \mathrm{~N} \mathrm{HCl}$ was added upto the mark. The solution was filtered and diluted suitably and drug content in the samples was estimated using UV-spectrophotometer at 248 nm. ${ }^{14}$ 


\section{In-vitro buoyancy studies}

Tablets were kept in a $100 \mathrm{ml}$ beaker containing $0.1 \mathrm{~N} \mathrm{HCl}$ (pH 1.2). The duration required for the $\mathrm{QF}$ floating tablet to increase to the surface and float was determined as floating lag time (FLT). The total duration of QF floating tablet continuously present on the surface was carried out as the total floating time. 15, 16

\section{In-vitro drug release}

It was conducted for a period of $12 \mathrm{~h}$ using USP XXIV type-II (Paddle) dissolution apparatus at $37 \pm 0.5^{\circ} \mathrm{C}$ at $50 \mathrm{rpm}$ utilizing $900 \mathrm{ml}$ of $0.1 \mathrm{~N} \mathrm{HCl}$ as dissolution medium. At predetermined interval of time, ten ml of sample was taken from the dissolution medium and replaced with $0.1 \mathrm{~N} \mathrm{HCl}$ to maintain the constant volume. After sample solution was filtered and diluted sufficiently, it was analyzed at $248 \mathrm{~nm}$ by UV-Visible spectrophotometer. ${ }^{17}$

\section{In-vitro release kinetic study}

The drug release data of floating tablets was fitted to kinetics models, that is, zero order, first order, higuchi and Korsemeyer-Peppas to find out drug release pattern and mechanism. ${ }^{18}$

\section{RESULTS AND DISCUSSIONS}

Drug -excipients compatibility study by FTIR:

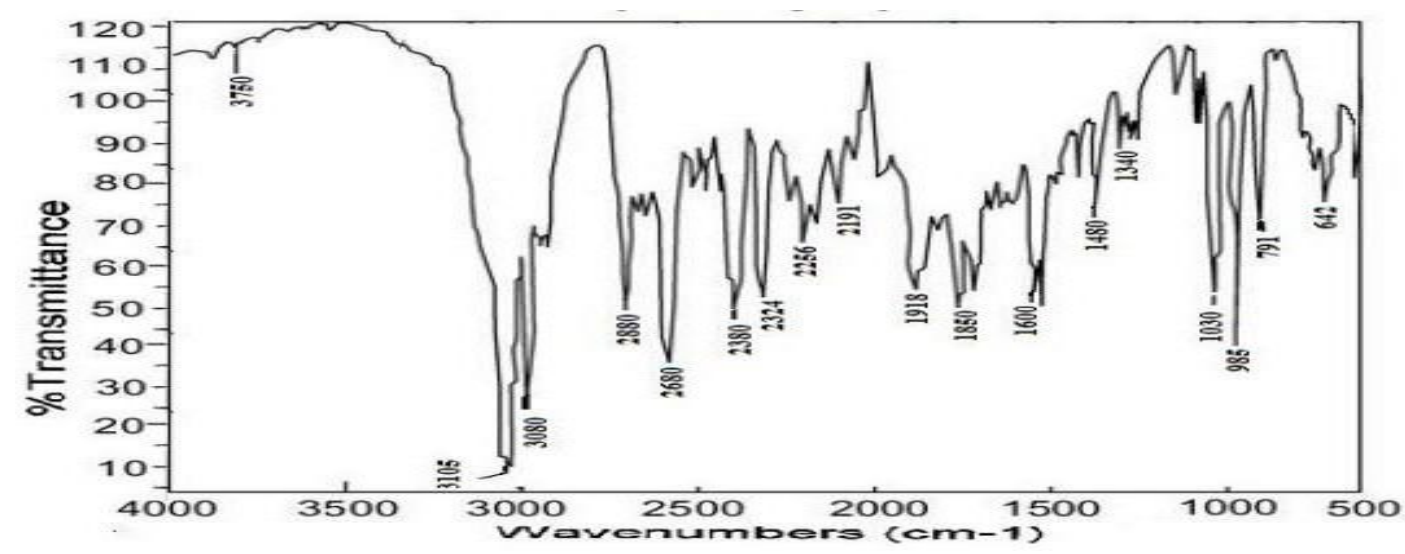

Figure 1: IR Spectra of Quetiapine Fumarate

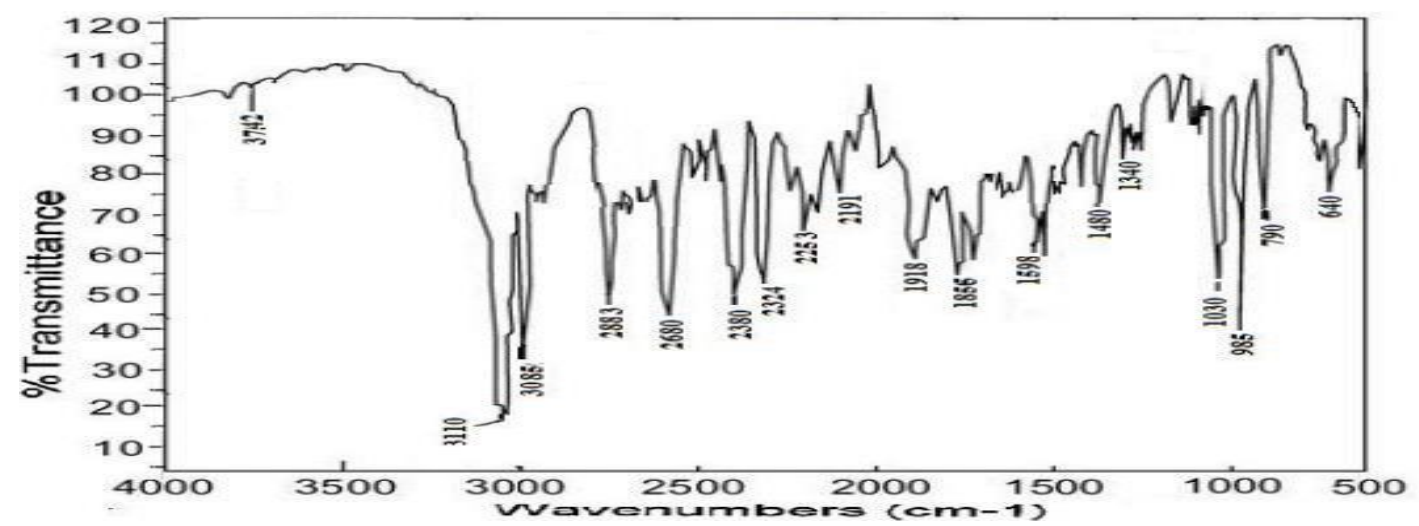

Figure 2: IR spectra of Physical mixture

From the IR studies (Figure 1and 2), important function group IR bands of QF and physical mixture were identified. Characteristic IR bands of QF includes the peaks at $3750 \mathrm{~cm}$ 1 (O-H stretching), $2880 \mathrm{~cm}^{-1}$ (C-H stretching), $2380 \mathrm{~cm}^{-1}$ (aromatic C=C stretching), $1600 \mathrm{~cm}^{-1}$ (C-N stretching), 1340 $\mathrm{cm}^{-1}$ (C-H bending) and $1030 \mathrm{~cm}^{-1}$ (C-O-C stretching) which remained unaltered in IR spectrum of physical mixture of
QF and polymers. IR analysis showed that there was not any interaction between $\mathrm{QF}$ and polymers.

\section{Factorial design batches tablet evaluation parameters}

Prepared all batches QF tablets were assessed for weight variation, thickness, hardness, \% friability and \% of drug content. (Table 3). 
Table 3: Results of factorial design batches tablet evaluation

\begin{tabular}{|c|c|c|c|c|c|}
\hline Batch code & $\begin{array}{c}\text { Weight variation } \\
\text { (mg)* }\end{array}$ & Thickness(mm)\# & $\begin{array}{l}\text { Hardness } \\
\left(\mathrm{kg} / \mathrm{cm}^{2}\right) \#\end{array}$ & \%Friability \$ & \%Drug Content \$ \\
\hline F1 & $252 \pm 2.21$ & $4.53 \pm 0.10$ & $5.9 \pm 0.31$ & $0.82 \pm 0.12$ & $98.81 \pm 1.12$ \\
\hline $\mathbf{F} 2$ & $251 \pm 2.22$ & $4.53 \pm 0.14$ & $5.0 \pm 0.22$ & $0.65 \pm 0.08$ & $98.72 \pm 0.95$ \\
\hline F3 & $250 \pm 2.47$ & $4.52 \pm 0.19$ & $5.8 \pm 0.45$ & $0.87 \pm 0.13$ & $98.65 \pm 1.78$ \\
\hline F4 & $253 \pm 2.18$ & $4.51 \pm 0.09$ & $5.1 \pm 0.21$ & $0.67 \pm 0.11$ & $99.85 \pm 1.22$ \\
\hline F5 & $251 \pm 2.59$ & $4.50 \pm 0.12$ & $5.2 \pm 0.58$ & $0.60 \pm 0.18$ & $99.53 \pm 1.87$ \\
\hline F6 & $250 \pm 2.15$ & $4.48 \pm 0.18$ & $5.2 \pm 0.26$ & $0.62 \pm 0.17$ & $99.16 \pm 1.71$ \\
\hline F7 & $252 \pm 2.36$ & $4.47 \pm 0.17$ & $5.4 \pm 0.32$ & $0.52 \pm 0.12$ & $98.32 \pm 1.91$ \\
\hline F8 & $254 \pm 1.95$ & $4.45 \pm 0.12$ & $6.3 \pm 0.12$ & $0.47 \pm 0.15$ & $99.44 \pm 1.42$ \\
\hline F9 & $252 \pm 2.42$ & $4.46 \pm 0.16$ & $5.4 \pm 0.49$ & $0.51 \pm 0.14$ & $98.60 \pm 1.89$ \\
\hline
\end{tabular}

*n=20, \# n=5, \$= 10 (mean \pm SD)

The prepared tablets were smooth and white to off white color. Hardness of the QF floating tablets was in the range of $5.1-6.3 \mathrm{~kg} / \mathrm{cm}^{2}$. Weight variation in all above batches of $\mathrm{QF}$ tablets was within $\pm 2.5 \%$ of theoretical tablet weight and within the acceptance criteria. The prepared tablets showed in range thickness of 4.45-4.53 mm. \% drug content of QF floating tablets was found between $98.32 \%$ to $99.85 \%$. Friability of $\mathrm{QF}$ tablets was less than $1 \%$ in all factorial batches.

\section{In-vitro buoyancy studies (Table 4)}

The floating lag time was found between $25 \pm 2 \mathrm{sec}$ to $178 \pm$ $3 \mathrm{sec}$ QF tablets were prepared by effervescent technique using $\mathrm{NaHCO}_{3}$ as a gas forming agent. $\mathrm{NaHCO}_{3}$ produced $\mathrm{CO}_{2}$ liberation in presence of acid. The liberated gas is protected within the gel. Then polymer is hydrated and reducing the tablet density. As the tablet density falls below $1 \mathrm{~g} / \mathrm{ml}$, the tablet becomes buoyant.1, 19-20 The effect $\mathrm{NaHCO}_{3}$ on tablets buoyancy was evaluated by using it at three different levels 25, 35 and $45 \mathrm{mg}$ per tablet. Lowest FLT was found in batch F3 which contain $45 \mathrm{mg} \mathrm{NaHCO} 3$ and $60 \mathrm{mg}$ natrosol 250 HHX. Highest FLT was found in batch F7 which contain 25 mg $\mathrm{NaHCO}_{3}$ and 90mg natrosol $250 \mathrm{HHX}$. All QF floating tablets of factorial batches maintained their matrix integrity for more than $9 \mathrm{~h}$. So from the result it was concluded that
FLT decreases with increasing amount of $\mathrm{NaHCO}_{3}$. It was due to increased amount of carbon dioxide as the concentration of $\mathrm{NaHCO}_{3}$ was increased, being entrapped in the formed gel to give rapid buoyancy.

Table 4: floating lag time and floating time of F1-F9 batches

\begin{tabular}{|c|c|c|}
\hline $\begin{array}{c}\text { Batch } \\
\text { code }\end{array}$ & $\begin{array}{c}\text { Floating LagTime } \\
\text { (sec) }\end{array}$ & $\begin{array}{c}\text { Total FloatingTime } \\
\text { (h) }\end{array}$ \\
\hline F1 & $153 \pm 2$ & 9 \\
\hline F2 & $38 \pm 3$ & 9 \\
\hline F3 & $25 \pm 2$ & 9 \\
\hline F4 & $165 \pm 3$ & 12 \\
\hline F5 & $48 \pm 2$ & 12 \\
\hline F6 & $40 \pm 2$ & 12 \\
\hline F7 & $178 \pm 3$ & 13 \\
\hline F8 & $60 \pm 2$ & 13 \\
\hline F9 & $48 \pm 2$ & 13 \\
\hline * $\mathrm{n}=5(m e a n \pm S D)$ & &
\end{tabular}

\section{$\%$ In-vitro drug release}

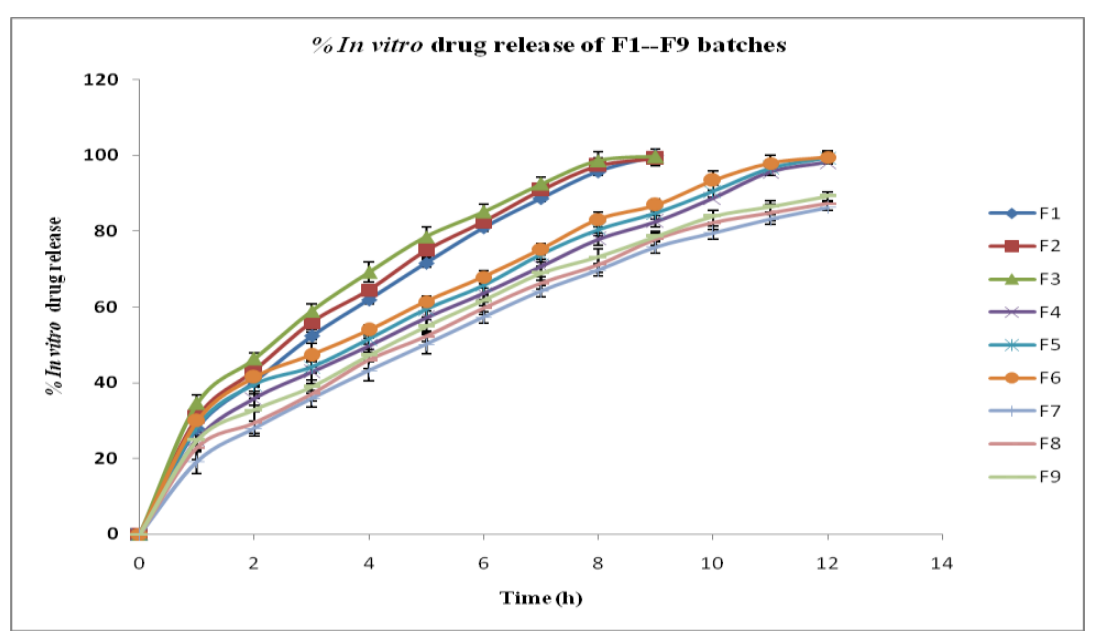

Figure 3: In vitro drug release data of F1-F9 batches 
It was showed that the drug release was higher in case of $\mathrm{F} 1$, F2 and F3 batch while drug release was lower in case of F7, F8 and F9 batch. Batch F1 and F7 showed the $95.82 \%$ and $69.67 \%$ at $8 \mathrm{~h}$ respectively. It indicates that as the amount of natrosol $250 \mathrm{HHX}$ increase in formulation, the drug release decrease. It may be due to formation of more viscous gel layer around the tablet at high concentration of polymer.

\section{Factorial design analysis}

Analysis of factorial batches data was done using Design Expert DoE software. The data compiled for the selected responses and data analysis was done. Table 5 was used for data analysis.

Table 5: $3^{2}$ factorial design layout

\begin{tabular}{|c|c|c|c|c|c|}
\hline \multirow{2}{*}{$\begin{array}{c}\text { Batch } \\
\text { code }\end{array}$} & \multicolumn{2}{|c|}{ Independent variable } & \multicolumn{3}{|c|}{ Dependent Variables } \\
\cline { 2 - 6 } & $\begin{array}{c}\mathbf{X}_{\mathbf{1}} \\
\text { HHX (mg) }\end{array}$ & $\begin{array}{c}\mathbf{X}_{\mathbf{2}} \\
\text { Sodium } \\
\text { Bicarbonate }(\mathrm{mg})\end{array}$ & $\begin{array}{c}\mathbf{Y}_{\mathbf{1}} \\
\text { \% drug release at 1 h }\end{array}$ & $\begin{array}{c}\mathbf{Y}_{\mathbf{2}} \\
\text { \% drug release at 8 h }\end{array}$ & $\begin{array}{c}\mathbf{Y}_{\mathbf{3}} \\
\text { Floating lag time } \\
(\mathrm{s})\end{array}$ \\
\hline F1 & 60 & 25 & $27.94 \pm 2.45$ & $95.82 \pm 1.89$ & $153 \pm 2$ \\
\hline F2 & 60 & 35 & $30.81 \pm 2.34$ & $97.33 \pm 2.11$ & $38 \pm 3$ \\
\hline F3 & 60 & 45 & $34.82 \pm 2.18$ & $98.61 \pm 2.45$ & $25 \pm 2$ \\
\hline F4 & 75 & 25 & $24.92 \pm 3.19$ & $77.92 \pm 1.69$ & $165 \pm 3$ \\
\hline F5 & 75 & 35 & $28.52 \pm 3.26$ & $80.54 \pm 1.67$ & $48 \pm 2$ \\
\hline F6 & 75 & 45 & $29.93 \pm 2.49$ & $83.12 \pm 1.98$ & $40 \pm 2$ \\
\hline F7 & 90 & 25 & $19.24 \pm 3.14$ & $69.81 \pm 1.62$ & $178 \pm 3$ \\
\hline F8 & 90 & 35 & $22.92 \pm 3.28$ & $71.23 \pm 2.16$ & $60 \pm 2$ \\
\hline F9 & 90 & 45 & $24.52 \pm 2.91$ & $73.22 \pm 2.11$ & $48 \pm 2$ \\
\hline
\end{tabular}

Regression analysis for the effect of $\mathrm{X}_{1}$ and $\mathrm{X}_{2}$ on $\mathrm{Y}_{1}$

Table 6: ANOVA table for response $\mathrm{Y}_{1}$

\begin{tabular}{|l|l|l|l|l|l|l|}
\hline Source & $\begin{array}{l}\text { Sum of } \\
\text { Squares }\end{array}$ & DF & Mean Square & F-value & P-value & Remarks \\
\hline $\begin{array}{l}\text { Model } \\
\text { (Quadratic) }\end{array}$ & 177.05 & 5 & 35.41 & 136.98 & $<0.0001$ & Significant \\
\hline $\mathrm{X}_{1}$ & 117.84 & 1 & 117.84 & 455.83 & $<0.0001$ & Significant \\
\hline $\mathrm{X}_{2}$ & 50.87 & 1 & 50.87 & 196.77 & $<0.0001$ & Significant \\
\hline $\mathrm{X}_{1}{ }^{2}$ & 4.00 & 1 & 4.00 & 15.48 & 0.0056 & Non- Significant \\
\hline $\mathrm{X}_{2}{ }^{2}$ & 1.14 & 1 & 1.14 & 4.43 & 0.0735 & Non- Significant \\
\hline $\mathrm{X}_{1} \mathrm{X}_{2}$ & 0.42 & 1 & 0.42 & 1.63 & 0.2419 & Non- Significant \\
\hline
\end{tabular}

$\mathrm{Y}_{1}=+28.39-4.43 * \mathrm{X}_{1}+2.91 * \mathrm{X}_{2}-1.20 * \mathrm{X}_{1}{ }^{2}-0.64 * \mathrm{X}_{2}{ }^{2}-0.32 * \mathrm{X}_{1} \mathrm{X}_{2}$

Where, $\mathrm{X}_{1}=$ Natrosol $250 \mathrm{HHX}, \mathrm{X}_{2}=$ Sodium Bicarbonate

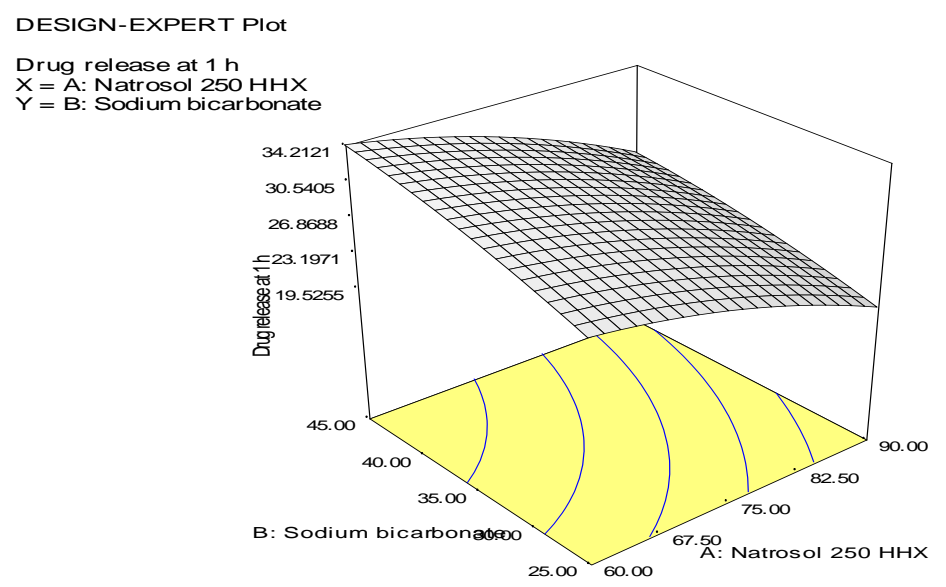

Figure 4: Surface plot for $\mathrm{Y}_{1}$

From the equation (1), it was concluded that $X_{1}$ had negative $\& \mathrm{X}_{2}$ had positive effect on $\mathrm{Y}_{1}$. So it was concluded that $\%$ drug release at $1 \mathrm{~h}$ decreased with an increase the amount of natrosol 250 HHX and decrease the amount of sodium bicarbonate. 
Regression analysis for the effect of $X_{1}$ and $X_{2}$ on $Y_{2}$

Table 7: ANOVA table for response $Y_{2}$

\begin{tabular}{|c|c|c|c|c|c|c|}
\hline Source & Sum of Squares & DF & Mean Square & F-value & P-value & Remarks \\
\hline $\begin{array}{c}\text { Model } \\
\text { Quadratic }\end{array}$ & 1069.51 & 5 & 213.90 & 978.04 & $<0.0001$ & Significant \\
\hline $\mathrm{X}_{1}$ & 1001.04 & 1 & 1001.04 & 4577.13 & $<0.0001$ & Significant \\
\hline $\mathrm{X}_{2}$ & 21.66 & 1 & 21.66 & 99.04 & $<0.0001$ & Significant \\
\hline $\mathrm{X}_{1}{ }^{2}$ & 39.69 & 1 & 39.69 & 181.46 & $<0.0001$ & Significant \\
\hline $\mathrm{X}_{2}{ }^{2}$ & 2.601 & 1 & 2.601 & 0.012 & 0.9162 & Non- Significant \\
\hline $\mathrm{X}_{1} \mathrm{X}_{2}$ & 0.096 & 1 & 0.096 & 0.44 & 0.5286 & Non- Significant \\
\hline
\end{tabular}

$\mathrm{Y}_{2}=+80.53-12.92 * \mathrm{X}_{1}+1.90 * \mathrm{X}_{2}+3.79 * \mathrm{X}_{1}{ }^{2}+0.031 * \mathrm{X}_{2}^{2}+0.15 * \mathrm{X}_{1} \mathrm{X}_{2}$

DESIGN-EXPERT Plot

Drug release at $8 \mathrm{~h}$

$\mathrm{X}=\mathrm{A}$ : Natrosol $250 \mathrm{HHX}$

$\mathrm{X}=\mathrm{A}:$ Natrosol $250 \mathrm{HHX}$
$\mathrm{Y}=\mathrm{B}$ : Sodium bicarbonate

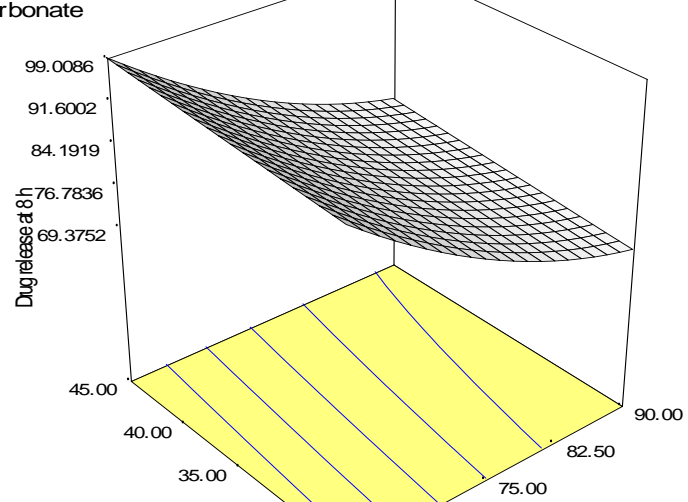

B: Sodium bicarbonaøøo 67.50 : Natrosol $250 \mathrm{HHX}$

$25.00 \quad 60.00$

\section{Figure 5: Surface plot for $Y_{2}$}

From the equation (2), it was concluded that $\mathrm{X}_{1}$ had negative \& $\mathrm{X}_{2}$ had positive effect on $\mathrm{Y}_{2}$. So it was concluded that \% drug release at $8 \mathrm{~h}$ decreased with an increase the amount of natrosol $250 \mathrm{HHX}$ and decrease the amount of sodium bicarbonate

Regression analysis for the effect of $\mathrm{X}_{1}$ and $\mathrm{X}_{2}$ on $\mathrm{Y}_{3}$

Table 8: ANOVA table for response $\mathrm{Y}_{3}$

\begin{tabular}{|l|l|l|l|l|l|l|}
\hline Source & Sum of Squares & DF & Mean Square & -value & P-value & Remarks \\
\hline $\begin{array}{l}\text { Model } \\
\text { Quadratic) }\end{array}$ & 1069.51 & 5 & 213.90 & 978.04 & $<0.0001$ & Significant \\
\hline $\mathrm{X}_{1}$ & 1001.04 & 1 & 1001.04 & 4577.13 & $<0.0001$ & Significant \\
\hline $\mathrm{X}_{2}$ & 21.66 & 1 & 21.66 & 99.04 & $<0.0001$ & Significant \\
\hline $\mathrm{X}_{1}{ }^{2}$ & 39.69 & 1 & 39.69 & 181.46 & $<0.0001$ & Significant \\
\hline $\mathrm{X}_{2}{ }^{2}$ & 2.601 & 1 & 2.601 & 0.012 & 0.9162 & Non- Significant \\
\hline $\mathrm{X}_{1} \mathrm{X}_{2}$ & 0.096 & 1 & 0.096 & 0.44 & 0.5286 & Non- Significant \\
\hline
\end{tabular}

$\mathrm{Y}_{3}=+48.34+11.67 * \mathrm{X}_{1}-63.83 * \mathrm{X}_{2}-0.21 * \mathrm{X}_{1}{ }^{2}+53.29 * \mathrm{X}_{2}{ }^{2}-0.50 * \mathrm{X}_{1} \mathrm{X}_{2}$ 


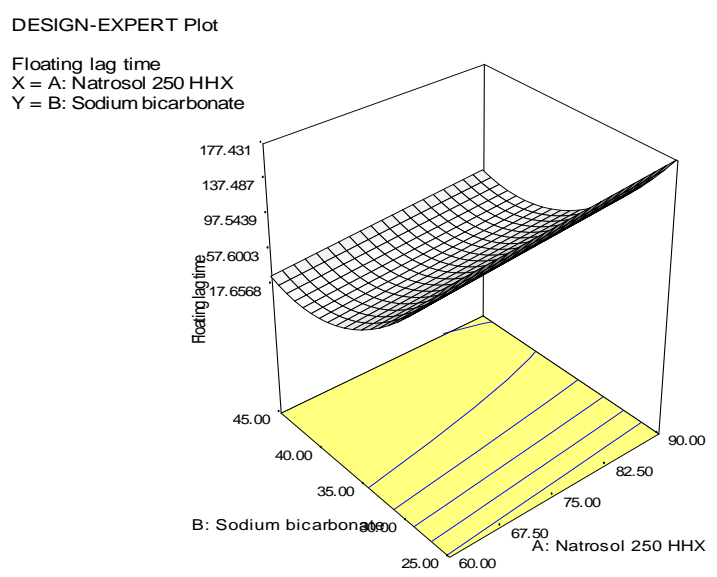

Figure 6: Surface plot for $\mathrm{Y}_{3}$

From the equation (3), it was concluded that $\mathrm{X}_{1}$ had positive $\& X_{2}$ had negative effect on $Y_{3}$. So it was concluded that floating lag time decreased with decrease the amount of natrosol 250 HHX and increase the amount of sodium bicarbonate.

\section{Check point batch analysis (Validation of design)}

To assess the validity of prediction, a checkpoint batch $\mathrm{C} 1$ and C2 was prepared and evaluated under the same conditions as outlined for the other batches. The response data was compared with that of required data. The obtained response variables of check point batch compared with target response parameters. The bias for predicted versus observed responses was acceptable. The Check point batch $\mathrm{C} 1$ and C2were prepared and results of check point batches are shown in Table 9.

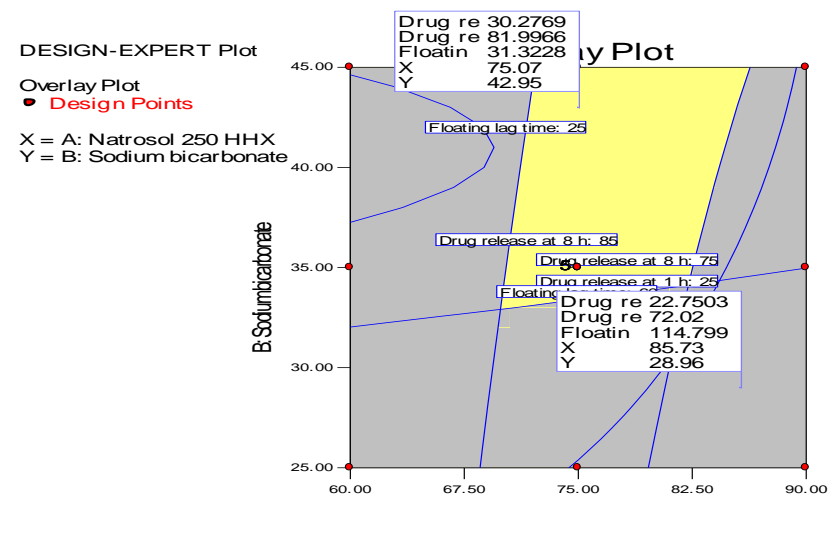

Figure 7: Overlay plot of check point batches

Table 9: Results of check point batches

\begin{tabular}{|c|c|c|c|c|c|}
\hline \multirow{2}{*}{$\begin{array}{l}\text { Batch } \\
\text { code }\end{array}$} & \multirow{2}{*}{$\begin{array}{c}\text { Natrosol } 250 \text { HHX } \\
\text { (mg) }\end{array}$} & \multirow{2}{*}{$\begin{array}{c}\text { Sodium Bicarbonate } \\
\text { (mg) }\end{array}$} & \multicolumn{3}{|c|}{$\%$ Drug release at $1 \mathrm{~h}$} \\
\hline & & & Predicted & Observed & $\%$ Bias \\
\hline $\mathrm{C} 1$ & 75.07 & 42.95 & 30.27 & 31.22 & 3.13 \\
\hline $\mathrm{C} 2$ & 85.73 & 28.96 & 22.75 & 22.16 & 2.59 \\
\hline Batch & Natrosol 250 HHX & Sodium Bicarbonate & \multicolumn{3}{|c|}{$\%$ Drug release at $8 \mathrm{~h}$} \\
\hline code & (mg) & & Predicted & Observed & $\%$ Bias \\
\hline $\mathrm{C} 1$ & 75.07 & 42.95 & 81.99 & 80.80 & 1.45 \\
\hline $\mathrm{C} 2$ & 85.73 & 28.96 & 72.02 & 71.15 & 1.20 \\
\hline \multirow{2}{*}{$\begin{array}{l}\text { Batch } \\
\text { code }\end{array}$} & Natrosol 250 HHX & Sodium Bicarbonate & \multicolumn{3}{|c|}{ Floating time (sec) } \\
\hline & (mg) & & Predicted & Observed & \% Bias \\
\hline C1 & 75.07 & 42.95 & 31 & 32 & 3.22 \\
\hline $\mathrm{C} 2$ & 85.73 & 28.96 & 114 & 110 & 3.50 \\
\hline
\end{tabular}


Observed value of $\mathrm{C} 1$ and $\mathrm{C} 2$ batch was measured and compared with the predicted value of check point batch. \% error was found to be less than 5 of all the responses. Hence, this model was valid and optimized batch can be selected from the overlay plot of this model.

\section{Optimized batch}

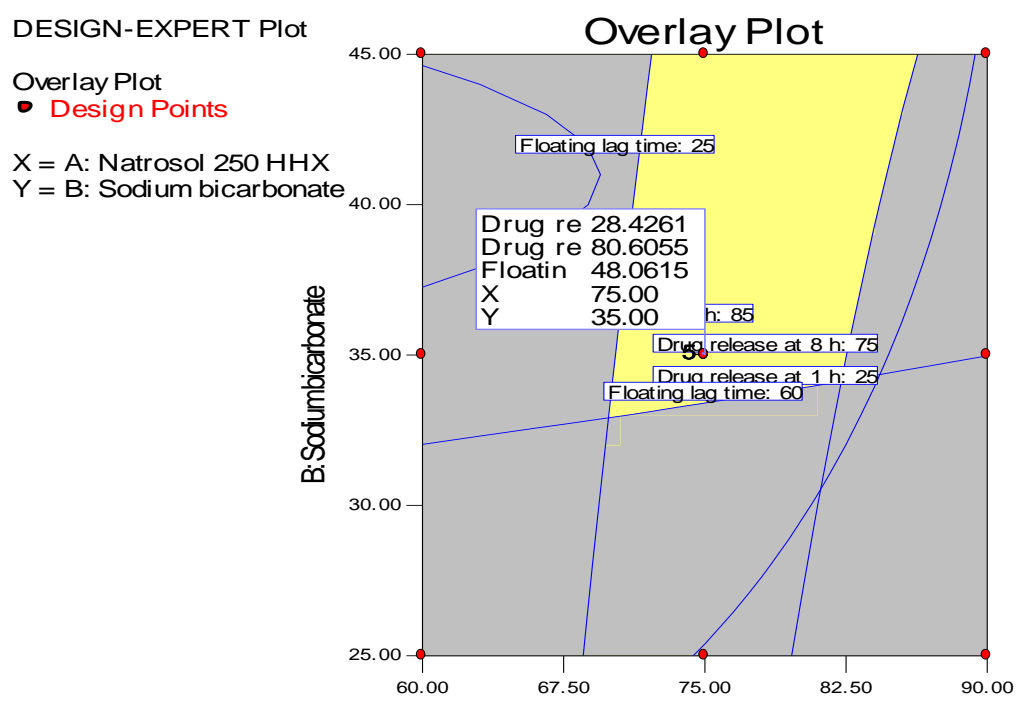

A: Natrosol $250 \mathrm{HHX}$

Figure 8: Overlay plot of optimized batch

Table 10: Results of optimized batch 01

\begin{tabular}{|c|c|c|}
\hline Evaluation Parameters & \multicolumn{2}{|c|}{ Results } \\
\hline Weight variation (mg) & \multicolumn{2}{|c|}{$252 \pm 2.22$} \\
\hline Thickness(mm) & \multicolumn{2}{|c|}{$4.51 \pm 0.11$} \\
\hline Hardness $\left(\mathrm{kg} / \mathrm{cm}^{2}\right)$ & \multicolumn{2}{|c|}{$5.2 \pm 0.81$} \\
\hline Friability (\%) & \multicolumn{2}{|c|}{$0.59 \pm 0.09$} \\
\hline Drug Content (\%) & \multicolumn{2}{|c|}{$99.2 \pm 1.92$} \\
\hline Floating Lag Time (sec) & \multicolumn{2}{|c|}{$49 \pm 3$} \\
\hline Total Floating Time (h) & \multicolumn{2}{|c|}{$12 \mathrm{~h}$} \\
\hline \multirow{9}{*}{ \% Drug Release } & Time (h) & \% Drug Release \\
\hline & 0 & 0 \\
\hline & 1 & $27.82 \pm 2.92$ \\
\hline & 2 & $38.33 \pm 2.23$ \\
\hline & 4 & $54.51 \pm 1.95$ \\
\hline & 6 & $66.36 \pm 2.61$ \\
\hline & 8 & $80.24 \pm 1.74$ \\
\hline & 10 & $91.61 \pm 1.12$ \\
\hline & 12 & $99.54 \pm 0.81$ \\
\hline
\end{tabular}

Here in Figure 8 shows the yellow area was the optimized area and batch 01was fall in the yellow region. The optimized batch 01 was prepared and results of optimized batch are shown in Table 10.The tablets have uniform drug distribution hence drug content was found satisfactory.
Weight variation also found well within acceptable range. Thickness was found uniform. In vitro buoyancy studies properties also found satisfactory. \% CDR was found 27.82 \pm $2.92,80.24 \pm 1.74$ and $99.54 \pm 0.81$ at $1 \mathrm{~h}, 8 \mathrm{~h}$ and $12 \mathrm{~h}$ respectively. 
In vitro release kinetic studies

Table 11: In vitro release kinetic studies of optimized batch

\begin{tabular}{|c|c|c|c|c|}
\hline Model & Zero order & $1^{\text {st }}$ order & Higuchi & Korsmeyer -Peppas \\
\hline $\mathrm{R}^{2}$ & 0.9872 & 0.9240 & 0.9968 & 0.9976 \\
\hline Slope (n) & 6.51 & 0.0479 & 29.51 & 0.5182 \\
\hline Intercept & 25.47 & 1.4841 & -3.33 & -0.5661 \\
\hline
\end{tabular}

The in vitro release profile of drug from all the formulations could be best expressed by Korsmeyer-Peppas model, as the plot shows high linearity $\left(\mathrm{R}^{2}=0.9976\right)$. The " $\mathrm{n}$ " value was found to be 0.5182 in Korsmeyer- Peppas model, so it follows non-fickian diffusion or anomalous diffusion mechanism [Table 11].

\section{CONCLUSIONS}

Quetiapine fumarate floating tablets successfully prepared by using natrosol $250 \mathrm{HHX}$ as a sustained release polymer and sodium bicarbonate as a gas forming agent. Concentration of Natrosol 250 HHX had significant effect on $\%$ in-vitro drug release and FLT. It was found that increase the concentration of polymer resulted that increased FLT and reduced the release rate. In-vitro release kinetics revealed Korsmeyer-Peppas model is followed and drug release is by anomalous diffusion. From the study it can be conclude that floating tablets of quetiapine fumarate an innovative and promising perspective for the delivery of quetiapine fumarate as extended drug release over $12 \mathrm{~h}$ which is better formulation in the schizophrenia therapy with minimizing the adverse effects and improves patient compliance.

\section{REFERENCES}

1. Gharti KP, Thapa P, Budhathoki U, Bhargava A, Formulation and in vitro evaluation of floating tablets of hydroxypropyl methylcellulose and polyethylene oxide using ranitidine hydrochloride as a model drug, J Young Pharmacists 2012; 4(4):201-208. https://doi.org/10.4103/0975-1483.104363

2. Dehghan MH, Khan FN, Gastroretentive drug delivery systems: A patent perspective, Int J Health Res, 2009; 2(1):23-44. https://doi.org/10.4314/ijhr.v2i1.55385

3. Mathur P, Saroha K, Syan N, Verma S, Kumar V, Floating drug delivery systems: An innovative acceptable approach in gastroretentive drug delivery, Arch Apll Sci Res, 2010; 2:257270 .

4. Juthi AZ, Bithi TZ: Gastroretentive drug delivery technologies: review. World Journal of Pharmaceutical and Medical Research, 2018; 4(2):11-15.

5. Prajapati H, Patel K, Gupta AK, Formulation and evaluation of floating microspheres of baclofen, Int J Pharm Sci \& Res, 2021; 12(3):1482-1494.

6. Amritha V., Kaur S , Pandey K, Formulation and in vitro evaluation of floating tablets of hydroxypropylmethylcellulose K4M and carbopol using metronidazole as model drug, International Journal of Pharmaceutical Science and Research, 2014; 5(6):2244-2249.

7. Yerikala R, Pudi V, Saravanakumar K, Vadhireddy S. Formulation and evaluation of floating drug delivery of cefotaxime using raft forming approach, Journal of Drug Delivery and Therapeutics, 2017; 7(4):110-119. https://doi.org/10.22270/jddt.v7i4.1473

8. Soni H, Ghulaxe C, Upadhyay S, Pillai S, Development and in vitro evaluation of an oral floating tablet of metronidazole, Journal of
Drug Delivery and Therapeutics, 2018; 8(2):83-86. https://doi.org/10.22270/jddt.v8i2.1673

9. Kandukoori NR, Shanthi MS, Sushma J, Ramya C, Swapna M, Madhu G, Deepika B, Rao KNV, Dutt RK: A review on floating drug delivery system, World Journal of Pharmaceutical Research, 2017; 6(5):553-568. https://doi.org/10.20959/wjpr20175-8451

10. Someshwar K, Suryakanta S, Muddana E, Bhanoji R, Bikash RJ, Sambamoorthy U, Vishali D, QbD-based design and characterization of mucoadhesive microspheres of quetiapine fumarate with improved oral bioavailability and brain biodistribution potential. Bulletin of Faculty of Pharmacy, Cairo University, 2018; 56(2):129-145. https://doi.org/10.1016/j.bfopcu.2018.09.002

11. Figueroa, C, Brecher, M, Hamer-Maansson, JE, Winter $H$, Pharmacokinetic profiles of extended release quetiapine fumarate compared with quetiapine immediate release. Prog. Neuro-Psychopharmacol. Biol. Psych., 2009; 33(2):199-204. https://doi.org/10.1016/j.pnpbp.2008.09.026

12. Ukawala R, Singhvi G, Jain S, Shukla V, Yadav N, Sharma S. Design and characterization of controlled release gastro-retentive floating tablet of an atypical psychotropic agent, J Pharm Bioall Sci, 2012; 4(5):88-89. https://doi.org/10.4103/09757406.94151

13. Chandarana DA, Patel KS, Patel SC, Patel DR, Prajapati ST, Formulation and evaluation of mucoadhesive buccal tablets of carvedilol, Int J App Pharm, 2020; 12(4):170-181.

14. Poornima P, Abbulu K, Mukkanti K. Formulation and in-vitro evaluation of gastro-retentive floating tablets containing quetiapine fumarate. Int. J. Pharm. Sci. Drug Res., 2017; 9(6):315- 322. https://doi.org/10.25004/IJPSDR.2017.090605

15. Prajapati PH, Nakum VV, Patel CN. Formulation and evaluation of floating matrix tablet of stavudine. Int J Pharma Investig., 2012; 2(2): 83-89. https://doi.org/10.4103/2230-973X.100047

16. Pawar HA, Dhavale R, Development and evaluation of gastroretentive floating tablets of an antidepressant drug by thermoplastic granulation technique, Beni-Suef University Journal of Basic and Applied Sciences, 2014; 3(2):122-132. https://doi.org/10.1016/j.bjbas.2014.05.005

17. Patil M, Vidyasagar G, Patil VB, Formulation, optimization and evaluation of floating tablets clarithromycin. , Int J Pharm Pharm Sci, 2015; 7(5):320-326.

18. Patel KS, Patel MB. Preparation and evaluation of chitosan microspheres containing nicorandil. Int J Pharma Investig 2014; 4(1):32-37. https://doi.org/10.4103/2230-973X.127738

19. Patel, D.M., Patel, D., Patel, A., Sheth, A., Shah, U.J. Method Development and Validation for Simultaneous Estimation of Benidipine Hydrochloride and Metoprolol Succinate in Tablet. Journal of Drug Delivery and Therapeutics. 2019; 9 (6s):28-33. https://doi.org/10.22270/jddt.v9i6-s.3692

20. Gambhire MN, Ambade KW, Kur mi SD, K adam VJ, Jadhav KR. Development and in vitro evaluation of an oral floating matrix tablet formulation of diltiazem hydrochloride. AAPS PharmSciTech 2007; 8(3):E73. https://doi.org/10.1208/pt0803073 